\title{
THE IMPLEMENTATION OF RELIGIOUS PLURALISM VALUES OF ISLAMIC LAW ON ARTICLE 156A OF THE CRIMINAL CODE
}

\author{
Rossa Ilma Silfiah ${ }^{1}$ \\ 1Faculty of Social and Policy, University of Yudharta Pasuruan \\ Email: rossa@yudharta.ac.id
}

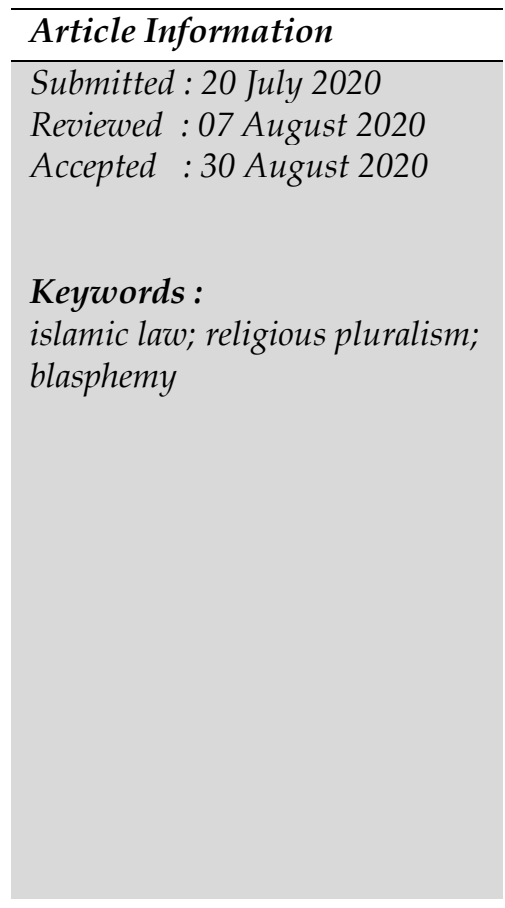

\begin{abstract}
Religious freedom in Indonesia is based on the abundant presence of Godliness that is the religious values embraced in Indonesia. The religions are Islam, Christianity, Catholicism, Hinduism, Buddhism and Confucianism mentioned in the Presidential Decree No. 1 of 1965 on the defamation/blasphemy, and stipulation of Article 156 a to become a part of Article 156 Criminal Code. The essence of the blasphemy law is to realize a harmonious religious life. This is in line with the Islamic law that is universal and dynamic. Islam does not deny the diversity of the universe, diversity of knowledge, diversity of tribes and cultures, and diversity of religions and beliefs. Because the messenger of the Prophet was to improve the morality of his followers by carrying the value of Rahmatan lil-aalamiin (a blessing for the universe). In this study, the values of Islamic law implicit in Article 156 a of the Criminal Code were examined by applying a normative method as well as religious text approach as a framework for argumentation. In addition to applying a policy-oriented approach, this research also applied a value-oriented approach. Because the position of Islamic law is one source of material law as well as very relevant to the pluralistic style of Indonesian society.
\end{abstract}

\section{Introduction}

Miriam Budiardjo, identified the function of state, the first: a state apart from its ideology - is carrying out law and order, maintaining unity as a nation/state, and maintaining public security. The second is to strive for prosperity and guarantee the prosperity of the people, both in material and spiritual aspects. The third is defense, which is to guard against all possible attacks from outside. The fourth is upholding justice through the judiciary. (Miriam Budiardjo, 1982) Sudikno Mertokusumo argued that the function of law is to protect of human interests. This is in line with the main purpose of law that is to realize order and balance in society, so that the people interests can be protected. (Sudikno Mertokusumo, 1995)

According to Philipus M. Hadjon, legal protection for the people is "rechtsbescherming van de burger stegen de overheid, or legal protection of the individual in relation to act of administrative authorities. Furthermore, Hadjon added that legal protection for the people is preventive and repressive legal protections. (Philipus Hadjon, 2007) Preventive legal protection is intended to avoid blasphemy, violence in the name of 
religion, destruction of worship houses and others. While, repressive protection aims to resolve conflicts occurred.

The United Nations declared Human Rights on December 10, 1948, three years after Indonesian independence on August 17, 1945. The regulation on religious rights is regulated in Article 18 right to freedom of thought and religion, which reads:

"Everyone has the right to freedom of thought, conscience and religion; this right includes freedom to change his religion or belief, and freedom, either alone or in community with others and in public or private, to manifest his religion or belief in teaching, practice, worship and observance."

Indonesia as a member of the United Nations, of course, has carried out the mandate while still considering the religious pluralism character of Indonesian people. Pancasila as the ground norm, has become the hallmark of the Indonesian people in realizing a religious society. Freedom of religion in the Pancasila legal state is always in a positive connotation meaning that there is no place for atheism or anti-religious propaganda in Indonesia. (Tahir Azahary, 2003) So that freedom of religion in Indonesia is different from, for example, United States of America and Soviet Union who understand it positively and negatively, in the sense of opening up opportunities and providing constitutional guarantees for atheism.

Freedom of religion in the Pancasila is always in a positive connotation meaning that there is no place for atheism or anti-religious propaganda in Indonesia. The assertion that "the Abundant presence of Godliness" (Article 29 paragraph (1) of the 1945 Constitution of the Republic of Indonesia) has the consequence that Indonesia does not sterilize the role of religions in the administration of the state, but on the contrary Indonesia also cannot refer to only one religion. Therefore, the affirmation that Pancasila State is neither "a religious state" nor "a secular state" is a lead to find legal ideals that are in accordance with social and cultural values as a reflection of Indonesian people.

Religious freedom is part of the securities given by the state to citizens as the implementation of Article 29 of the 1945 Constitution of the Republic of Indonesia which states that the State is based on the abundant presence of Godliness, and in the second paragraph gives freedom for religious adherents to practice their religion. It is stated in Law No. 39 of 1999 on Human Rights in Article 4, saying:

"The right to life, the right not to be tortured, the right to personal freedom, mind and conscience, the right to religion, the right not to be enslaved, the right to be recognized as individuals and equality before the law and the right not to be prosecuted on the basis of a retroactive law are rights human rights that cannot be reduced under any circumstances and by anyone".

Specifically in Law No. 39 of 1999 on Human Rights is written in Article 22 Paragraph (1), saying: "Everyone is free to embrace their 
respective religions and to worship according to their religion and beliefs". Then continued in paragraph (2), which reads: "The state guarantees the freedom of every person to embrace their respective religions and to worship according to their religion and beliefs".

\section{Research Methods}

This article is result of normative legal research using statute approach and historical approach to examine the history behind issuing Act 156a of the Criminal Code and find out the philosophy development in line with issuance Act of 156a of the Criminal Code. (Peter Mahmud, 2013) In this study, the values of Islamic law implicit in Article 156a of the Criminal Code were examined by applying a normative method as well as religious text approach as a framework for argumentation. In addition to applying a policy-oriented approach, this research also applied a valueoriented approach. Because the position of Islamic law is one source of material law as well as very relevant to the pluralistic style of Indonesian society.

\section{Research Result and Discussion}

\section{A. The Presence Of Article 156a Of The Criminal Code}

Muhammad Tahir Azhary explained in detail the relationship between religion, law, and state by calling the Theory of Concentric Circles. The three components - religion, law, and state - will form a concentric circle which is a unity and is closely related to one aother, when put together. Religion as the first component, is in the fundamental circle followed by law which occupies the next circle. The effect of religion on the law is huge, because religion is the main source of law beside the ratio as a complementary source. State as the third component is in the last circle. The position shows that the state includes the two previous components, namely religion and law in this concentric circle. (Tahir Azahary, 2003)

\section{Chart 1}

\section{Concentric Circle}

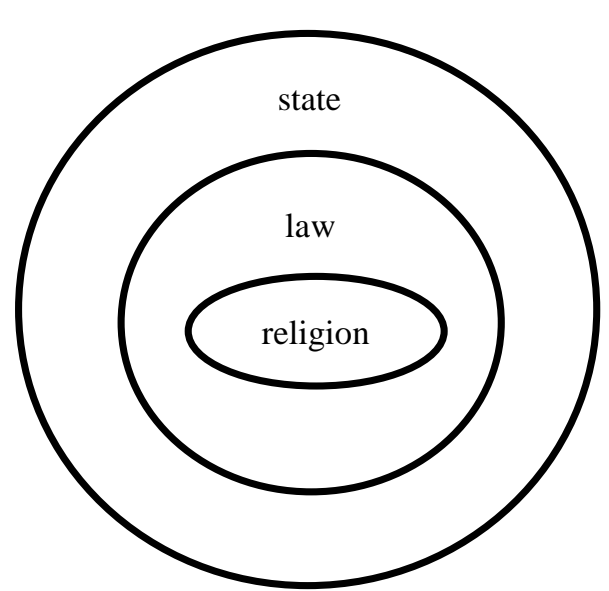

Source: Bahan Hukum Sekunder, Muhammad Tahir Azhary, 2003 
In general, legal policy or legal reform in Islam highly considers the benefit of the community. The rule of ushul figh states that tasharruful imaam 'alarra'iyyah manuthun bil-mashlahah, which means the policy of leaders over their people must consider the benefit of society at large. Benefit in this case includes the people's welfare. This people's welfare can be achieved by eliminating harm/damage, one of which is manifested in the enforcement of criminal law.

Policies or preventions toward crime are essentially an integral part of efforts to realize social defense social welfare. Therefore, the ultimate goal of the criminal policy is the protection for society to achieve the people's welfare. It can also be said that criminal policy is basically an integral part of social policy, in which policies or efforts to achieve social welfare. As the following chart: (Barda Nawawi, 2014)

\section{Chart 2 \\ Criminal Policy}

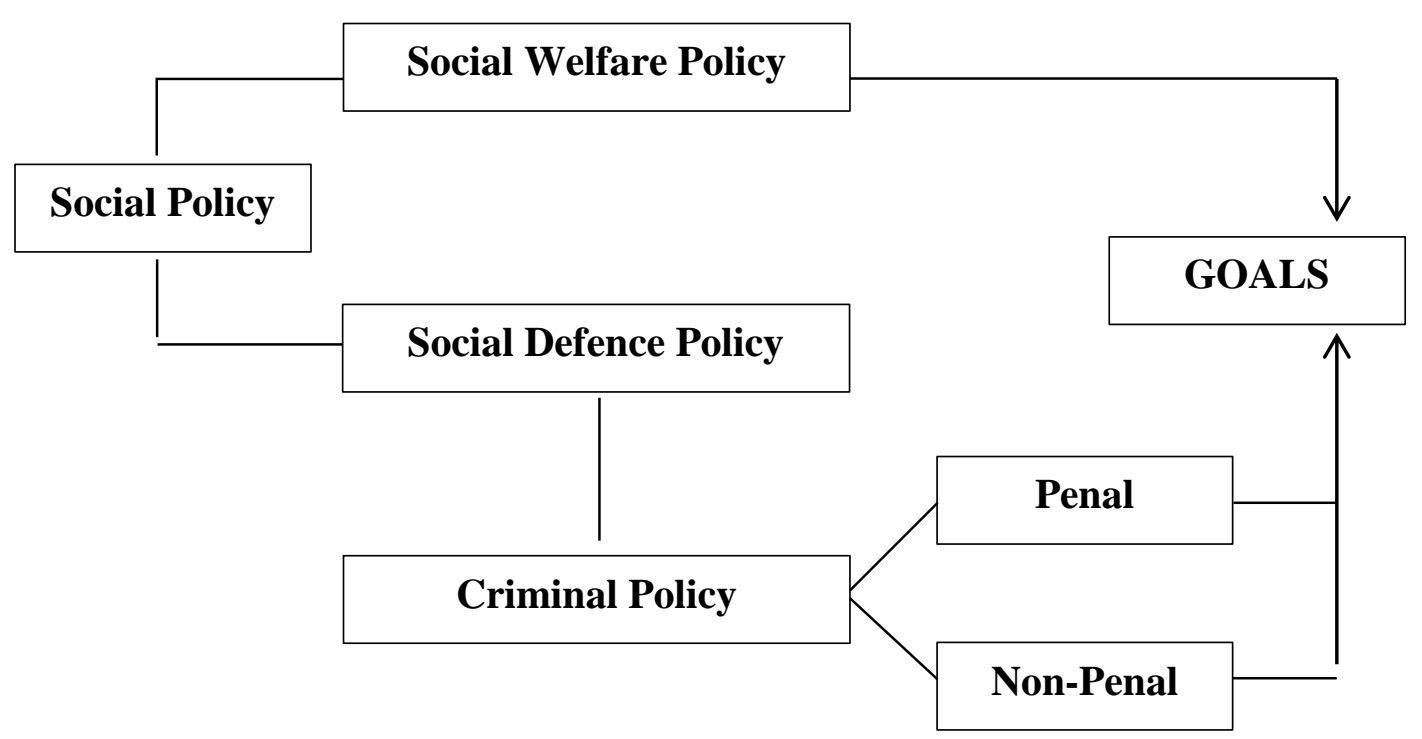

Source: Bahan Hukum Sekunder, Barda, 2014

State policies related to the criminalization of blasphemy are part of prevention efforts by imposing sanctions to perpetrators which are not regulated in the previous Criminal Code. The implementation of first Sila, saying the abundant presence of Godliness, is a philosophical foundation and a strong foundation for the formation of religious offenses. So that the National Law Seminar I of 1963 had been the background of the birth of Law Number 5 of 1965 concerning Prevention of Abuse and / or Blasphemy of Religion (hereinafter referred to as the PNPS Law). From Article 4 of the PNPS Law, \the addition of a new Criminal Code article was formulated, named Article 156a which states:

"In the Criminal Code, a new article is added which reads as follows: 
Article 156a

"Convicted with imprisonment for up to five years, whoever deliberately publicly issues or acts:

a. Which is basically hostility, abuse, or blasphemy of the religion adhered to in Indonesia;

b. With the intention that people do not follow any religion, which is based on the abundant presence of Godliness".

The birth of PNPS Law No. 1 of 1965 on the Prevention of Abuse and / or blasphemy of Religion was motivated by various postindependence security conditions. Various parties acknowledged mutual contribution to fighting for the independence of the Republic of Indonesia at that time. So that various groups had the sense concerned to make this state fit to their respective group ideologies. Debate about the State Ideology and the Constitution could hardly accommodate all interests one by one. So, it needed a power to make them aware.

In the period of 1959 - 1965, President Sukarno with the Guided Democracy System became an authoritarian leader. The parties which were rife in the Liberal Democracy Era were practically weak and powerless, except for the Indonesian Communist Party which could expand its influence by taking refuge under Sukarno's rule; while the Army can expand its role and political power. (Mahfud MD, 1998) The outbreak of the G30S/PKI in 1965 had undermined Sukarno's power with his authoritarian guided democracy. This event ended the tensions between the three political forces; Sukarno, Army, and PKI.

Sukarno was dismissed constitutionally by the Provisional People's Consultative Assembly (MPRS) because it could not give responsibility for the G30S/PKI National Disaster. Finally, PKI was dissolved and declared a prohibited party because it had betrayed the state. The military appeared as the main actor in the early political stage of the New Order, an era that was used as the official name to replace the Guided Democracy Era (19591966), known as the Old Order. (Mahfud MD, 1998)

Formally, the entry into force of Article 156a of the Criminal Code through PNPS Law No. 1 of 1965 is valid, because it is based on Article 1 of the Transitional Rules of the 1945 Constitution of the Republic of Indonesia. Materially, the substance of the Law on Prevention, defamation and/or blasphemy of religion is in accordance with Pancasila and the 1945 Constitution of the Republic of Indonesia. However, in its application it must clarify the formulation, form, and limitations. So that law enforcement related to blasphemy can be assertive and meet the sense of justice of individuals, communities, and countries. Developments that have taken place in the reformation era have seen significant social changes, especially related to the understanding of human rights, especially religious freedom.

\section{B. Islamic Law Objectives}


The Prophet Muhammad was sent to perfect the morals of his followers, as in the Hadith: innama bui didn'tstu liutammma Makaarimal akhlaaq. Tolerance is a good form of morality. Tolerance is a term in the social, cultural, and religious context which means attitudes and actions that prohibit discrimination against groups who are different or unacceptable to the majority in a society. Such as religious tolerance, in which adherents of the majority in a society permit the existence of other religions. The word Toleransi is an absorption form English "tolerance". The definition is also not much different. In Arabic, the term commonly used as an equivalent to the word tolerance is "samaahah" or "tasamuh". This word basically means al-jud (honor) or sa'at al-shadr (graceful) and tasahul (friendly, forgiving). This meaning subsequently developed into graceful attitude in the face of differences that stem from a noble personality.

Protecting religion is also an obligation for every Muslim, since revelation came to the Prophet Muhammad. By protecting religion, it has automatically protected religious life. Because the concept of Islamic Aqeedah must be followed by Islamic Sharia and actualized in the life of the nation and state called good Islamic morality. The obligation to protect religion has been explained in the Quran, Surah Muhammad verse 7: "O believers, if you help (religion) Allah, surely He will help you and strengthen your position". The study of the protection of religion is actually similar to the study of protection of humans as a whole. Because in the Qur'an it has been stated that the purpose of human creation is to worship God (Allah). As in Surah Adz-Dzariyat verse 56: "And I did not create jinn and human, but that they worship Me".

The verse confirms that the creation of human is only to worship his God, so everything performed by humans is inseparable from the creation purpose. As a consequence, Allah made signs for humans through His sharia both human deeds to Allah (hablun minallah), and human deeds with each other (hablun minannaas).

The human relationship to his God has been arranged in the main points of the teaching called Aqeedah. The position of aqeedah in Islam is as a principle that is built on religious regulations (sharia). While sharia is the result of being born by the aqeedah. Thus, there are no rules / sharia in Islam but because of the existence of aqeedah. Then, sharia without aqeedah is like a tall building without a foundation. Aqeedah also does not rely on abstract power which presents inspiration to place sharia and maintain its rules. (Mahmud Syaltut, 1986)

\section{Protection Toward Religion In Islamic Law}

Islam reflected by some groups currently is in sharp contrast to the religious-pluralism spirit mentioned in the Qur'an. Furthermore, some of these Islamic groups claim to be the most absolute Islamic group. This actually shows the teachings of Islam that are less sympathetic. Whereas 
in Surah Al-Hajj verse 40, Allah provides protection for all houses of worship, not only mosques.

The history of violence and radicalism in all religions always presented the name of God. This can be understood because the power of idea "in the name of God" is very powerful. This power can exceed all existing claims of political authority. This is because religious ideology can be raised to the supernatural level. "In the name of God" can be used as a spirit of radicalism and even justification of all human actions.

Religious radicalism is indeed felt very terrible. Starting from disbelieving people of different opinions, to attacking people in entertainment establishments, killing doctors and nurses in abortion clinics, attacking and killing enemies with different ideologies, even overthrow and kill the president for the sake of religion. Thus according to Karen Armstrong in his book "Battle for God: Fundamentalism in Judaism, Christianity, and Islam." (Junaidi Abdillah, 2014)

Of course, such a reflection of Islam is very contrary to the true teachings of Islam. Islam strongly opposes radicalism. Islam promotes tolerance between religious communities in a single unified nation. This was proven by the Prophet Muhammad in the Constitution of Medina. In Indonesia, the absorption of Islamic law in national law is a necessity, because the majority of Indonesian society is Muslim where there are parts of Islamic law that can be implemented completely requiring the role and support of the state. Therefore, the absorption of Islamic law in national law can be realized in line with the spirit of unity in diversity within the framework of the Unitary Republic of Indonesia. This is because Islamic law is all beneficial for humanity and the universe, so that there will be no discrimination against citizens of different cultures and religions.

The pattern of absorption can be performed in three ways, namely formal, substantial, and essential depending on the material and scope of application. First, formal (rasmiah) patterns. Formal means the formal absorption of Islamic law into national law. There are parts of Islamic law that must be adopted in national law formally and only apply to Muslims, such as zakat, waqf, religious court, and pilgrimage. Second, substantial (dzatiah). The teachings of Islam are universal (rahmatan lil alamin). For this reason, NU strives to make the values of Islamic teachings to have good impact not only by the Indonesian people but by all mankind. Because the socio-political system of the Indonesian people has not yet allowed the formal implementation of Islamic teachings, it is necessary to fight for the values of substance in legislation, such as the issues of pornography, gambling, drug abuse, and others. Third, essential (ruhiah) is related to the diversity of the Indonesian people and supports the establishment of the Unitary Republic of Indonesia. Therefore, in the application of sharia, it is necessary to use a gradual (tadriji) pattern to avoid community rejection which results in counterproductive for the development of sharia socialization in the future. (Hasyim As'ari) 
Because Islamic law is not yet possible to implement, it is necessary to include the essence of Islamic law in the applicable laws in Indonesia. As in Islamic criminal law, it is not necessary to push for the enactment of Islamic jinayah law formally or substantially, but to adopt the essence of jinayah law. For example, a crime against an adulterer (ghairu muhson) which in the Criminal Code is not considered a criminal, it is necessary to strive to become a criminal offense with $\mathrm{ta}^{\prime}$ zir punishment.

The purpose of applied Islamic Law are to maintain the religion (hifdhuddiin), to maintain the soul (hifdhunafs), to maintain mind (hifdhul'aql), to maintain heredity (hifdhunnasl), and to maintain property (hifdhulmaal). Anyone is recommended to do his religious lesson in order to keep himself to always rely on the religious rule. He also should keep healthy, forbidden to attack each other or even killing one and another, in order to keep himself alive. Human is forbidden to consume liquor, drugs, or anything in similar, in order to keep his minf healthy. Human is forbidden to do adultery, to keep his heredity from destruction of his order or origin. The forbidden of stealing or riba, even corruption is to keep his property to always use his property in good way.

Protection of religion (hifdh al-diin) in Islamic law is the first objective of law. This opinion is very popular among the Fuqahaa' which was sparked by Abu Ishak Al-Syathiby with the theory of Maqasid alSyar'i. The purpose of protecting the religion has power of syar'i law where the God message and al-Hadith as its content. The whole contents principally purpose to keep and protect the religion and religious application to the human being, thus, the religious reputation keep awake and sustainable in any period. Furthermore, the warning of al-Qur'an on the freedom to have religion by stating laa ikraaha fiddiin "...there is no force in religion" (Al-Baqarah: 256) refer to fundamental legal norm that must be obeyed absolutely without reserve. (Thohir Luth, 2011) Thus, no doubt that Islam respect the freedom of embracing religion. To protect the freedom of religion, Al-Qur'an give limitation of the freedom. Some verses explained on criminal action toward religion and religious life, however, generally it stated in Al-Qur' an in Surah Al-Mai'dah, verse 33;

Indeed, the penalty for those who wage war against God and His Messenger and strive upon earth [to cause] corruption is none but that they were killed or crucified or that their hands and feet were cut off from opposite sides or that they were exiled from the land. That is for them a disgrace in this world; and for them in the Hereafter is a great punishment".

In line with the history of coming down this verse (asbab al-nuzul), told by Abdul Malik bin Marwan wrote letter to Anas, asking about this verse. Anas answered by explaining that this verse came down related to the tribe of Urainah that apostate from Islam and killed camel herder then took away his camel. This verse was threat of punishment for those who make destruction in the world. (Qamaruddin Shaleh, 1990) However, the redaction of this verse is general, (Quraisy Shihab, 2001) then of course - 
according to the rules of interpretation of the Qur'an - understanding of the text of the verse is not based on the cause of the fall, but based on the general redaction. (Abdurrahman Nashir, 1997) (Al'ibratu bi 'umumi allafdzi, la bi khushushi al-sabab).

Most interpreters of the Qur'an provide the interpretation that is meant by those who fight against Allah and His Messenger is to fight against the sharia of Allah, the religion of Allah, and custodian of Allah, to make mischief on earth by doing evil and bloodshed. (Ali Ash-Shobuni, 1986) Ahmad Mushtafa Al-Maraghi interpreted the verse innama jazaau alladzina yuharibuna Allah wa al-rasulahu, as a crime that violates the truth and justice that Allah has sent down on His Messenger. Because by committing these crimes, it means disobedience to the religion and sharia of Allah. (Musthafa Al-Maraghi) While, according to Fakhruddin Ar-Razi in the Book of Tafsir Al-Kabir. ${ }^{1}$ (Manna' Al-Qaththan, 1996) that the sentence fighting against Allah and His Messenger is Majaz, because humans cannot possibly fight against directly. But it means disobedience to the laws of Allah and His Messenger. (Fakhruddin Ar-Razi, 1990)

The sentence wa yas'auna fi al-ardli fasada, as explained by Ahmad Mushtafa Al-Maraghi, refer to make destruction on the earth is action committed by destructors (terrorists, pen) who destruct the relation among the people, in form of social regulation (law, pen) or living infrastructures. (Al-Maraghi) The kinds of destruction are many and different in any period and places, as well as the dangers are different. There can be murder, robbery, and breach of honor, destructing plants, heredity, and many others.

In line with these crimes, the government can impose punishments as stated in the versw; killed for those killer, crucifixion for robber, cutting off of hands and feet from opposite sides the thief or exile/deported from the area/country for the rogues. (Haliman, 1970) Thus, this verse states on kind of punishments decided by sharia. Almost in all book of interpretation do not give clarification that the verse explain on hirobah that generally clarified as robbery by fiqh expert; the fiqh books directly make this verse as legal basis for robbery. For, it related on the background of why the verse coming down (asbab al-nuzul).

Therefore, the verse clearly refer to universal one and may be applied to all kind of criminal conducts including Criminal Conduct of Religion and Religious Living. With four choices of punishments stated in the verse, the country has authority to decide kind of punishment applied to the criminal action.

\section{Tolerance of Islam Toward Adherents of Other Religions}

\footnotetext{
${ }^{1}$ There are 2 clasifications of the Book Interpretation, that Tafsir bi al-Ma'tsur interpreting Al-Qur'an with Al-Qur'an and Al-Hadits functioning to explain the Book of Allah, through stories of the prophet's companions. This book known in Indonesia, such as: Tafsir Al-Thobari, from Iman Al-Thobari. The second is Tafsir Bi al-Ra'yi, interpretation of verses of Al-Qur'an using opinion of mind, of course the mufassir must fill certain requirements. The Interpretation Book of Al-Kabir belong to the second category.
} 
The tolerant attitude in Islam refer to part of morality honor. That the Prophet Muhammad saw sent was purposed to complete the morality (innamaa bu'itstu li-utammima makaarimal-akhlaaq). All Islamic lesson, Aqeedah and Sariah, purposed for human being with his morality to do his duty as a leader or khalifah in this world. It means that only human has duty as khalifah (leader) among the creatures of Allah.

The life of religious adherents in Indonesia requires high tolerance attitude. Because there are several religions in Indonesian consisting of Islam, Christianity, Protestantism, Hinduism, Buddhism and Confucianism. On the other hand, there is also a background of various kinds of tribes and races that are very likely to have different views on one particular religion so that raises various differences in expressing religious values.

In this context, the Qur'an strictly forbids the imposition of coercion on others in order to convert to Islam. As regards Surah Al-Baqarah Verse 256:

"There shall be no compulsion in [acceptance of] the religion. The right course has become clear from the wrong. So whoever disbelieves in Taghut and believes in Allah has grasped the most trustworthy handhold with no break in it. And Allah is Hearing and Knowing".

This verse came down in connection with an event, as told by Ibn 'Abbas (an Ansar from Bani Salim bin'Awf), known by the name of Husain had two sons who were Christians. While he himself was Muslim. Husain asked the Prophet, "Do I have to force both (to convert to Islam)?" Then verse 256 of Surah Al-Baqarah came down. (Ali Ashobuni, 2012)

Islam's tolerance is mutual respect between adherents of different religions without confusing aqeedah. Because the question of aqeedah is a fundamental problem in all religions. So there is no tolerance in aqeedah in the sense of fusing and fusing together. (Kemenag RI, 2012) This explanation is stated in Surah Al-Kafirun as Surah Makiyah that was revealed in the Mecca period, although there is also an opinion which states that this surah revealed in the Medina period.

Imam Ibnu Katsir in his interpretation stated that surah of rejection toward all religious deeds conducted by infidels, and order that we should be sincere in our every religious deed to Allah, without any mixture; in the spirit, purpose, or form and procedure. Surah Al-Kafirun came down as well as answer of the offering from Quraisy to the prophet Muhammad. They were Aswad bin Abdul Muthalib, Umayah bin Khalaf, and Walid bin Mughirah came and asked the Prophet Muhammad to be more tolerant and compromise by switch in worship the god.

Surah Al-Kafirun was come down related to the asking of Quraisy to the Prophet Muhammad to take turn in do worship to their god and Allah worshiped by the Prophet Muhammad SAW. In a history stated: "Once, Walid bin Mughrah, al-'Ash bin Wail assahm. Al-Aswad bin Abdul Muthalib, Umayyah bin Khallaf and some other leaders of Quraisy 
came to the Prophet. They gave opinion to the Prophet by saying: 'What if we and you and all your folowers to worship the both of our gods? For example, in a year we together worship your god and the following year we together worship our god. We also can make alley in anything we considered good for both of us'. Then, the prophet answered their idea by saying, 'I shelter to Allah from associate Him. Then, coming down surah Al-Kafirun". (Kemenag RI, 2012) The following, the Prophet went to Haram Mosque to meet the Quraisy who sitting together and read Surah Al-Kafirun, thus, they had no hope to offer religious compromise to the prophet, since that time they showed their hostility clearly.

The explanation of interpretation and asbabun nuzul of Surah AlKafirun give two main opinions. First, swear of monotheism cannot be compromised between Islam aqeedah and other aqeedah. Second, swear of lillaahi ta'aalaa. In Islam, any form and practice of worships only for Allah, not for human being. Surah Al-Kafirun is closed with counter statement that is lakum diinukum waliyadiin (for you your religion, and for me my religion). Therefore, each religious adherents may do what he believed correct and good based on his belief without forcing his idea to other.

It need two approaches in facing religious plurality in social life: (Ali Makshum, 2011) First, approach based on principle of co-existence; the approach confessing that there is any differences of religions. This approach is applied in term of Aqeedah and Sariah, where all religions cannot be uniformed from one and other. Second, approach based on principle of pro-existence, the approach because of the same problem needed to solve together by all religions related to morality.

Strict attitude with religious lesson that can be mixed to other religion also stated in Surah Yunus verses 40 and 41, meaning:

"Of them there are some who believe therein, and some who do not: and thy Lord knoweth best those who are out for mischief."

"If they charge thee with falsehood, say: 'My work for me, and yours to you!' ye are free from responsibility for what I do, and I for what ye do!"

Allah SWT explained that unbelievers denying Al-Qur'an categorized into two. First, those who believe truly the good purpose of Al-Qur'an, they belong to people who honor other opinion. Second, those who do not believe at all and keep in their disbelief, they belong to people who make destruction. (Ali Ash-Shobuni, 1980) All conducts consist of consequence for the doer, as stated in Surah Yunus verse 41: lii 'amalii walakum 'amalukum (for you your working, for me my working). This verse explain that Islam really appreciate diversity among human being because each of them has right and cannot force others to embrace Islam. Let them do their worship based on their religion, as Moslem also need sense of safety in doing worship.

In addition, in Surah Yunus Verses 99 and 100 also explains that humans are given the freedom to believe or not in Him. Freedom is not 
sourced from human strength, but the gift of Allah. Because if Allah wills, surely all humans will believe in Him. However on the one hand, Allah also bestows intellectual so humans can use it to choose to believe or not in Him. For more details, here is the meaning of the verse:

"And had your Lord will, those on earth would have believed - all of them entirely. Then, [O Muhammad], would you compel the people in order that they become believers? And it is not for a soul to believe except by permission of Allah, and He will place defilement upon those who will not use reason".

This verse is addressed to the Prophet Muhammad who at that time was very persistent to urge mankind to believe, even the Prophet's attitude was very excessive and harming himself. The verse afa anta tukrihun-naasa (did you force the people?), On the one hand, to rebuke the Prophet, but on the other side also praised the sincerity of the Holy Prophet in preaching. Similar verses are found in Surah Fathir Verse 8: "Then do not you (Muhammad) let yourself perish because of sorrow towards them". (Kemenag RI, 2012)

Humans who have been given a warning, but do not heed will get the consequences of their actions. Allah and His Messenger did not lose at all by their actions. Based on his choices and actions, the human being is held accountable in the afterlife. As Surah Al-Kahf Verse 29:

"And say, "The truth is from your Lord, so whoever wills - let him believe; and whoever wills - let him disbelieve." Indeed, we have prepared for the wrongdoers a fire whose walls will surround them. And if they call for relief, they will be relieved with water like murky oil, which scalds [their] faces. Wretched is the drink, and evil is the resting place".

The principle of religious freedom shown at the beginning of this verse had been practiced by the Prophet Muhammad with the Shahifah of Medina (Medina Charter). Because no human being can show the truth, except from Allah. ${ }^{2}$ So the Medina Charter has inspired Muslims who live in the diversity of tribes, races and religions. Therefore, the principles are maintained with the preservation of the faith of each religion.

\section{Prohibition to Defame God of Other Religions}

Specifically, what regulates Criminal Acts against Religion and Religious Life is explained in verse 108 of Surah Al-An'am which mentions the prohibition of insulting worshipers:

"And do not insult those they invoke other than Allah, lest they insult Allah in enmity without knowledge. Thus we have made pleasing to every community their deeds. Then to their Lord is their return, and He will inform them about what they used to do."

\footnotetext{
${ }^{2}$ Regarding the truth of religion, the Qur'an has emphasized that the true religion is only the Islamic Religion as Sura Ali Imran Verse 19 innaddiina 'indallaahi al-Islaam (Surely the religion which is founded by Allah is only Islam. This verse is the basis for Muslims to strengthen their faith.
} 
This verse came down with regard to the Muslims who at that time liked to defame the idols of the polytheists, which resulted in the revenge of the polytheists to defame Allah. (Qamaruddin Shaleh, 1990) The purpose of this verse is that it is not permissible to defame the idolatrous worship of their idols, because such an act will surely cause the same attitude for the polytheists who would surely defame Allah without real knowledge and animosity. (Ali Ash-Shobuni, 1986) It should be noted that when this verse was revealed, the Messenger of Allah had two roles, besides being an Apostle who conveyed the teachings of Islam, he was also the Head of Government (Kukuh Tejomurti Tedjomurti, 2019: 199), apparently still promoting unity among religious communities.

\section{Protection of Worship Houses}

Al-Qur'an also give protection toward the houses of worship, not only the mosques, as stated in the Surah Al-Hajj verse 40:

"(They are) those who have been expelled from their homes in defiance of right, (for no cause) except that they say, 'Our Lord is Allah'. Did not Allah check one set of people by means of another, there would surely have been pulled down monasteries, churches, synagogues, and mosques, in which the name of Allah is commemorated in abundant measure? Allah will certainly aid those who aid His (cause); for verily Allah is Full of Strength, Exalted in Might, (able to enforce His Will)."

This verse gives outline of tolerance among the religious followers, that Islam keep all the worship places, Christian Monastery, churches, synagogues (houses of worship for the Jews) and mosques. The destruction of worship places refer to provocative action hurting religion and religious spirit of other religion, as well as becoming cause of state disintegration. Thus, the Islamic concept become merciful concept (adiluhung) as the example for protection of religions and religious living.

The placement of the list of worship houses has certain purpose. It does not mean the priority of Allah protection are monastery, church, synagogues and finally mosque. However, it is because the places are older according to the order of the prophets. Some believe that stating mosque in the last because it closer to the sentence "where many are called the names of Allah". (Al-Qurthubi) Mosque is place for Moslem where more people called the names of Allah than other places. In this place, the duty of prayer is conducted five times and other religious activity conducted.

Alwi Shihab, the teacher of Islamology in Universities Harvard, stated that there is no religion in the world that asks his followers to destroy the follower and religious places of other religion. If there is anarchy action as part of religious order, it happen because there is deviation of the religious lesson. (Muhammad Sofyan, 1999) Islam, as stated in Surah Al-Kafirun, and Surah Al-Baqarah verse 256 \{Laa ikraaha fiddiin $=$ there is no force in (follow) the religion (Islam) $\}$ has never order its followers to do fierce and force the follower of other religion to choose 
Islam. Also, the Catholic forbid its follower to kill the people of other religion, or to destruct other worship houses.

\section{Prohibition against Hostility of Infidels}

Respectful attitude and protecting non-moslem once practiced by the Prophet Muhammad saw when welcome the guest of Christian from Najran, at that time he serviced them with respectful, even he streched his turban and let the guest sat on it while they had a talk with full of harmony without showing any differences. Therefore, the prophet got angry when he heard murder toward non-moslem that commited by Moslem. The Prophet said, as told by Ibnu Mas'ud in Sunan Ibnu Majah, Ibnu Umar: "Whoever hurt non-moslem (dzimmy= infidels who make peace with Moslem), I will be his enemy. And whoever becoming my enemy in this world, I will make him my enemy in the judgment day". (HR. Ibnu Mas'ud, al-Jami' ash-Shaghir, hal. 158)

The hadith is only one of the Prophet's practices in fostering tolerance between religious communities. So, anyone who tries to tarnish the fraternity between religious communities, then it is worth to be imposed heavy sanctions. Because security and peace in life is a necessity for every human being. Al-amnu ahnal'aisy, al-luadlu aqwal-jaisy, which means that security is the best of life, and justice is a force beyond army. From here, security is a basic requirement for the implementation of life and human welfare. So with a sense of security, all freedom in carrying out religious teachings will be carried out properly, as the purpose of human life is to worship Allah.

\section{Conclussions}

Religious Law in Indonesia is the Source of National Law formulation in achieving the national legal system in accordance with the values of Pancasila. Pancasila makes Sila the Abundant presence of Godliness as the philosophical basis and the existence of Article 29 paragraph 1 which affirms that the State is based on the Abundant presence of Godliness is a constitutional basis in making religious law as the source of national law. Thus, Islam as one of the religions in Indonesia in social and juridical development has colored the formulation of national law since before the independence until now.

Islamic law with its universal nature is always present and able to answer the problems of this nation including very sensitive issues, such as the problem of blasphemy which currently often arises in the midst of social and political conflicts. The reform era, which demands the enforcement of human rights, has affected religious freedom in Indonesia. Religious freedom in Indonesia is a controlled freedom in accordance with the existing laws and regulations, because individual freedom will be faced with other individuals. The state efforts in realizing a harmonious 
state life turned out to be in line with the Qur'an text, Surah Al-Kaafiruun, which is essentially lakum dinukum waliyadiin (for you your religion, for me my religion) has formed a high tolerance for Indonesian Muslims, so that it becomes a role model for Muslims in other countries. In fact, the Qur'an also regulates the Prohibition to defame God of other religions, as in Surah Al-An'am verse 108. The Qur'an also protects all worship houses as in Surah Al-Hajj verse 40.

Article 156a of the Criminal Code is a state effort in the criminal sphere, and is very relevant to the values of Islamic Law. The Criminal Code does not protect one religion, because the state also does not mention a particular religion as an official religion. Indonesia is a state of Muslims (for Muslims), a state of Christians (for Christians), a state of Catholics (for Catholics), a state of Hindus (for Hindus), a state of Buddhists (for Buddhists), a state of Confucianism (for Confucianism). Because all religious people can practice their religious teachings peacefully in Indonesia.

\section{BIBLIOGRAPHY}

\section{Books:}

As-Sa'di, Abdurrahman Nashir, 1997, 70 Kaidah Penafsiran Al-Qur'an, Jakarta: Pustaka Firdaus.

Ash-Shobuni, Ali (1986). Shofwah al-Tafasir, Jakarta: Dar al-Kitab AlIslamiyah.

Al-Maraghi, Ahmad Mushtafa, Tafsir Al-Maroghi, Juz IV, Beirut Libanon: Dar al-Fikr.

Arief, Barda Nawawi (2014). Bunga Rampai Kebijakan Hukum Pidana: Perkembangan Penyusunan konsep KUHP Baru, Jakarta: Kencana Prenadamedia.

Al-Qaththan, Manna' (1996). Studi Ilmu-ilmu Al-Qur'an, Jakarta: Litera AntarNusa.

Ar-Razi, Fakhruddin, (1990). Tafsir Al-Kabir, Jilid XI-XII, Beirut: Dar alKutub al-Ilmiyyah.

Azahary, Muhammad Thahir (2001). Negara Hukum, Bogor: Kencana Prenada Medcia.

Budiardo, Miriam. (1982). Dasar-dasar Ilmu Politik, Jakarta: Gramedia.

Hadjon, Philipus M. (2007). Perlindungan Hukum Bagi Rakyat di Indonesia: Sebuah Studi tentang Prinsip-prinsipnya, Penanganannya oleh 
Pengadilan dalam Lingkungan Peradilan Umum dan Pembentukan Peradilan Administrasi, Jakarta, Peradaban.

Haliman (1970). Hukum Pidana Syari'at Islam Menurut Ahlu al-Sunnah wa alJama'ah, Bandung: Bulan Bintang.

Hamidi, Jazim, Husnu Abadi (2001). Intervensi Negara terhadap Agama, Yogyakarta: UII Press.

Kementerian Agama RI (2012). Tafsir Al-Qur'an Tematik: Hubungan Antar Umat Beragama, Jakarta: Aku Bisa.

Luth, Thohir. (2011). Syari'at Islam, Mengapa Takut?, Malang: UB Press.

Maksum, Ali (2011). Pluralisme dan Multikulturalisme, Paradigma Baru Pendidikan Agama Islam di Indonesia, Malang: Aditya Media Publishing.

Mahfud, Moh. MD (1998). Politik Hukum di Indonesia, Jakarta: LP3ES.

Marzuki, Peter Mahmud (2013). Penelitian Hukum, Kencana Prenada Media Group, Jakarta.

Mertokusumo, Sudikno. (1995). Mengenal Hukum, Yogyakarta, Liberty.

Pultoni, Siti Aminah, Uli Parulian Sihombing, 2012, Panduan Pemantauan Tindak Pidana Penodaan Agama dan Ujaran Kebencian atas Dasar Agama, (Jakarta: The Indonesian Legal Resource Center (ILRC)

Syaltut, Mahmud (1986). Islam; Aqidah dan Syari'ah, Jakarta: Pustaka Amani.

Sholeh, Qomaruddin, HAA. Dahlan, HMD. Dahlan, (1990). Asbabun nuzul: Latar Belakang Historis Turunnya ayat-ayat Al-Qur'an, Bandung: CY. Diponegoro.

Sofyan, Muhammad (1999) Agama dan Kekerasan Dalam Bingkai Reformasi, Media Pressindo, Yogyakarta.

Shihab, Quraisy (2001). Tafsir Al-Mishbah, Vol. 3, Jakarta: Lentera Hati.

\section{Journals:}


Gumbira, Seno Wibowo, I. Gusti Ayu Ketut Rachmi Handayani, and Kukuh Tejomurti Tedjomurti. (2019). "The Urgency of Presidential Policy to Revitalize and Maintain the Existence of Cooperatives Based on Pancasila." Sriwijaya Law Review 3.2 (2019): 199-224.

Hasyim Asy'ari. Relasi Negara dan Agama di Indonesia, Jurnal RechtsVinding Online, Media Pembinaan Hukum Nasional.

Junaidi Abdillah. (2014). Radikalisme Agama: Dekonstruksi Ayat-ayat Kekerasan dalam Al-Qur'an, Kalam: Jurnal Studi Agama dan Pemikiran Islam), Vol. 8 No. 2

\section{Legal Documents:}

The 1945 Constitution of The Republic of Indonesia

Indonesian Criminal Code

Law Number 1/PNPS/1965 on the Prevention of Defamation and/or Blasphemy of Religion

Law Number 39 of 1999 on Human Rights (State Gazette Number 165 of 1999) 